\title{
The Cultural Impact upon Human Struggle for Social Existence in Chinua Achebe's "Things Fall Apart"
}

\author{
Dr. Mohamed Fawzy El-Dessouky \\ English Department, Sohag High Institute for Social Work \\ Egypt, Sohag, El-Kawsar area \\ Tel: 002-010-976-9769 E-mail: mohameddessouky@hotmail.com
}

\begin{abstract}
This paper aims at introducing an insight into the nature of cultural conflict as depicted in Chinua Achebe's Things Fall Apart. This study shows how the African black culture represented by Ibo tribe comes into disagreement with the white one imposed by the British imperialism. The greatness of Achebe lies in the vivid description of place which is Nigeria and people who are the native Africans and how he was able to show the inner conflict that took place inside the major characters, like Okonkwo, in their pursuit of mere existence within a declining culture in the face of a tyrannical white one. The conflict has two aspects; an internal which can be traced within the same culture among its members and sometimes inside a specific character, on the other hand an external conflict took place between two cultures the African and the British one. The pursuit of mere existence is the dominant theme within this novel. It may be argued that Okonkwo's pursuit of existence represents the African culture itself in its endeavor for survival in the face of a domineering British one. Despite the fact that Okonkwo dies at the end, but it is quite evident that the African culture continued its struggle for existence in the hearts and minds of the new generation. All search for existence whether on individual level or cultural level.
\end{abstract}

Keywords: Conflict, Mere existence, Culture, Imperialism

Turning and turning in the widening gyre

The falcon cannot hear the falconer;

Things fall apart; the center cannot hold;

Mere anarchy is loosed upon the world,

The blood-dimmed tide is loosed, and everywhere

The ceremony of innocence is drowned;

The best lack all conviction, while the worst

Are full of passionate intensity.

(William Butler Yeats: "The Second Coming” 1921)

\section{African Writers and Literary Themes.}

After World War II, as Africans began demanding their independence, more African literature was published. In west Africa, such writers as, Wole Soyinka, Chinua Achebe, Ousmane Sembene, Kofi Awooner, Agostinho Neto, Tchicaya utam'si, Camera Laye, Mongo Beti, Ben Okri, and Ferdinand Oyono gained appreciative reputation and in east Africa, Ngugi wa Thiong'o, Okot p'Bitek, and Jacques Rabémananjara produced poetry, short stories, novels, essays, and plays. All were writing in European languages, and often most of them shared the same themes: the clash between indigenous and colonial cultures, condemnation of European subjugation, pride in the African past, and hope for the continent's independent future (The Columbia Encyclopedia 2007).

\subsection{Language of literature in Africa.}

For African literature to be given a chance of a worldwide audience, the writer is left with no choice but to write in French or English, or write in a native language and get translated into either French or English. Consider Nigeria, Chinua Achebe's homeland, a famous case in this respect; People of Nigeria speaks about half dozen or so languages, yet English gave them a language with which to talk to one another. Working on this belief, Achebe chose to tell his African stories, write his African novels in English, a language that would be able to bridge the barrier, both within the African continent and outside; a language that was part and parcel of the colonization process.

\section{Life and Background of Chinua Achebe}

The life of Achebe was full of many incidents and characters that had a great effect not only on him as a person but also on the style of his writing as well. Achebe was born on November 16, 1930 in Ogidi in the eastern region of 
Nigeria to a father who was an evangelist and church teacher. His maternal grandfather, like Okonknow in Things Fall Apart, was a wealthy and distinguished community leader.

Achebe received B.A. degree from university college Ibadan, in 1953. During the next twelve years he worked for the Nigerian broadcasting corporation. In 1961, he married Christiana Chinwe Okoli. During these years Achebe wrote his first four novels, beginning with his most famous Things Fall Apart in 1958, and ending with a Man of People in 1966. By 1966, Achebe had become a distinguished member of the international literary community.

However, his career was interrupted by the outbreak of the war in Biafra. Achebe joined the Biafran's ministry of information and played a diplomatic role in raising money for the Biafran cause. Bound as he was by emotional ties and personal commitment to his country's fate, Achebe had no time to write novels. All he could manage were short poems, which were published a year after the war was over in 1971.

After the war, Achebe's career was taken up primarily by the academic world. In 1972 he was a senior research fellow at the institute of African Studies at the University of Nigeria in Nsukka. From 1972 to 1975, he was a professor at the University of Massachusetts at Amherst, from 1975-1976 at the University of Connecticut. He then became professor at the University of Nigeria Nsukka and ten years later, he was again at university of Massachusetts.

In March 1990 Achebe was involved in a serious car accident that left him confined to a wheelchair. After nearly six months of recovery in various hospitals, he accepted an endowed professorship at Bard College in New York. For the next several years he turned his energies increasingly to the academic world teaching, editing and writing political and critical nonfiction.

\subsection{The Effect of Background life on Achebe's work.}

Things Fall Apart focuses on the early experience of colonialism as it occurred in Nigeria in the late 1800's, from the first days of contact with the British to the widespread British administration. Achebe is interested in showing Ibo society in the period of transition when rooted traditional values are put in conflict with an alien and more powerful culture that will tear them apart. Achebe paints a vivid picture of Ibo society both before and after the arrival of white men, and avoids the temptation to idealize either culture.

\section{Things Fall Apart: Origin and Contribution.}

Achebe takes the title of his first novel, Things Fall Apart, from W.B Yeast's 1921 poem The Second Coming, which prophesies the end of the present era and the entrance on the world's stage of another that is radically different. Things Fall Apart treats the early moments of that transition in an Ibo village. Achebe creates a mythic village whose history stretches back to a legendary past. Chapters are devoted to the daily routines of the people, their family life, their customs, games, and cruelties, their ancient wisdom, their social order, and legal practices. Achebe remains a realist since he identifies also certain flaws in the customs and in the people.

In the novel Things Fall Apart, Achebe presents to us a different perspective of life. He accomplishes this by introducing to us an African tribe named Ibo. There are tremendous differences between these people and the Europeans at the time. That is precisely why Achebe wrote this novel. He wrote it so that readers can learn about his beloved African culture. Another reason why he wrote? it is to show how easily a way of life can be destroyed. Things Fall Apart is about the fall of the African tribes with the colonization of Europeans. Lastly, Achebe wrote this novel to set a good example for his fellow Africans, so that they can follow his example and receive a good education. Achebe wants to promote modern African Literature. He wants to impress all of those who may misperceive his native African culture.

Things Fall Apart is Achebe's first novel and was published in 1958, a time often called the Nigerian Renaissance because in that period a large number of very strong Nigerian writers began to create a powerful new literature that drew on the traditional oral literature, European literature, and the changing times in Nigeria and in Africa at large. Writers as varied as Ben Okri and Wole Soyinka developed in the context of the ideas and energy of the Nigerian Renaissance, but Achebe is considered one of the earliest and best novelists to have come out of modern Nigeria, in fact one of the top English-speaking novelists of his time anywhere.

\subsection{Political Settings in Africa and Achebe's Things Fall Apart.}

When England sent colonizers and missionaries to Africa, it had great effect on African tribal life, and on Chinua Achebe. Achebe became slightly interested in British culture, and began reading English writings; only to be disgusted with the message British authors were trying to get across. Achebe learned that English authors saw Africans as inhumane savages that needed to be saved. Angry with the English writings, Achebe decided to answer back by writing his first novel, Things Fall Apart, in 1958, to counteract the distortions of English literature about 
Africa. In Things Fall Apart, Achebe tells the story of an Lbo village of the late 1800's and one of its great men, a warrior named Okonkwo. Okonkwo is a champion wrestler, a wealthy farmer, a husband to three wives, a title holder among his people, and a member of the select Egwugwu, whose members impersonate ancestral spirits at tribal rituals. However life changes dramatically for the lbo society and Okonkwo with the arrival of British colonizers and missionaries, also known as the white man.

The order of the Ibo society is disrupted with the appearance of the white man in Africa and with the introduction of white religion. Okonkwo, who is looked highly upon by his people, is unable to adapt to the changes that accompany colonialism. He tries to live the traditional Ibo life; however the arrival of the white man into his society causes him to fall apart. In the end of the story, Okonkwo, in frustration, decapitates an employed of the British, then commits suicide which is a sin against the tradition to which he had clung to. The conflict in the novel, vested in Okonkwo, derives from the series of crushing blows which are leveled at traditional values by an alien and more powerful culture causing, in the end, the traditional society to fall apart. In Things Fall Apart, Achebe recreated the tragic consequences that took place due to the clash between the Ibo society and the white man. By using a character such as Okonkwo, he showed how even the strong willed people of the Ibo society were unable to overcome the British influences.

Traditional way of living for the Ibo society was rapidly changing in the early 1900's due to European colonialism. Many Nigerians were being absorbed by the British and straying from their traditional beliefs and values. With the advent of the white man there was a loss of native values such as communal harmony, placing society above self, respect for the aged, and reverence for achievers, which resulted in the absence of self analysis and a stable code of ethics in the society of pre-Independent Nigeria. Lured by western education and well paying jobs, the youth of the country did not hesitate to stoop to the levels of immortality and dangerous permissiveness.

\subsection{A Multi-Thematic Novel of Conflict and Weakness.}

In Things Fall Apart, we see a conflict early in the novel between Okonkwo and his father, Unoka. Okonkwo thought of his father as a failure. Okonkwo did not take anything from his father starting the real world with nothing. Okonkwo's goal in life is to obtain great wealth and to have many wives and children. The people of Okonkwo's village considered this as a great status symbol. His greatest goal is his desire to become one of the powerful elders of the clan. Okonkwo saw his son, Nwoye, as gentle and forgiving. Okonkwo thought of these qualities as weak. Okonkwo also saw his son as lazy and wanted him to be a success like himself. Okonkwo's hard work pays off and helps him become one of the village's most respected members. Okonkwo establishes three out of four titles that are possible in the tribe.

Some of the conflicts contained religion, social life, education, and others. The Ibo people have a very different religious lifestyle than the British people. The Ibo believed in polytheism, the worship of many gods. The Ibo god that created the world and others is Chukwu. The Ibo had a group of nine ancestral spirits, which they called Egwugwu. The women of the Ibo people were monogamous believers. “'Every year'...'before I put any crop in the earth, I sacrifice a cock to Ani, the owner of all land"' (Achebe 17).

This is how religious the people of the tribe are. They worship all gods and believe that every god helps or harms them. When the Christian religion is introduced, many people of the Ibo became interested in this new religion. The most interested of the tribe were the people with the least titles. The British told the Ibo people that worship of polygamy is senseless and that there is only one god. 'Your gods are not alive and cannot do any harm,' Replied the white man. "They are pieces of wood and stone" (Achebe 105).

The man of the family has his own hut, which he lives in. The hut is also called an "obi" (Achebe 14). The woman shares a hut with the children of that same family. The tribe has a group of elders that have achieved a high status and help to keep order in the village. The elders ruled because it was thought that they are filled with knowledge. Women in the novel were depicted as not equal. Okonkwo even told himself once "he could remember when men were men" (Achebe 184). This is the time when the tribe does not choose to fight the missionaries.

The British destroyed many aspects of the Ibo culture. The "ebu" was one of the first to go. The ebu is the government system that the Ibo people incorporated. They also forced the natives to change their lifestyles. The British took over Umuofia, while introducing hospitals, courthouses, and jails. With the introduced court system, the missionaries are protected and only the Ibos are judged. The schools that the British built in Umuofia taught the native people to read and write in the white man's culture (Achebe 181).

Okonkwo's life finally fell completely apart as his body is found dangling from a tree. Okonkwo committed suicide. The reason that he did this is because he was ashamed of what the Ibo society was becoming. The British were taking over the whole culture, from taking the land to creating new beliefs. Some critics find Okonkwo's 
suicide ironic because suicide in the Ibo society is one of the worst acts a person can commit. Few civilizations were able to withstand the threat of Westernization. The force was too powerful, strong, and sophisticated for such common people to fight. Achebe tells the story with an understanding and personal experiences in both English and Native cultures. Achebe realized that neither of the cultures are bad, but they are simply different.

Throughout the novel, Achebe makes it clear the Ibo experience and love the natural world, and he uses metaphors to show their intimacy with the land. He writes, "Let the kite perch and let the eagle perch too. If one says no to the other, let his wing break" (Achebe 21-22). There are many sequences such as this in the novel, which show the stark beauty of Nigeria and what the people lost as the British built up and modernized the country. The natives were used to living off the land, while the British were not even interested in conserving or valuing the land.

In Things Fall Apart, though gender plays a significant factor in determining one's responsibilities, seniority does play a small factor. Women usually had domestically oriented jobs and complimentary positions to men. In the Ibo culture, women were expected to give birth to sons to prolong the survival of the tribe. A woman's main role was being a good loyal housewife. They were expected to look after the children, clean and have the meals ready by the time their husband at home. If they did not do all of their responsibilities, it was fair game for their husbands to beat them. Wife beating was considered a common solution to disobedient women, and was allowed by the Ibo tribe.

Chinua Achebe describes two instances of wife beating in Things Fall Apart. The first instance is when Okonkwo beats his wife, Ojiugo, and another involves a tribesman, Uzowulu. Okonkwo beats his wife first as a punishment for not having dinner prepared for him, for plaiting her hair instead of cooking dinner for him and his children.

Any other time, people would not have come over to see why a woman was screaming, but this was during the Week of Peace, and to beat someone during the Week of Peace was unheard of. Okonkwo did not care though. He thought that she needed to be punished anyway. Later, the priest called Okonkwo, and explained to him that he had greatly upset the gods, and in order to prevent them from pouring their wrath on the village, he had to bring many things to the Shrine of Ani.

Uzowulu had been accused by his sister-in-law of beating his wife too much. Once, he beat her while she was pregnant and she miscarried. This trial was brought before the Eegwugwu, or jury, because it was a more severe case. The Egwugwu ruled in favor of Uzowulu's wife, and he was ordered to bring a pot of wine to his in-laws and beg for his wife to return. After the case was over, one elder said to the other, "I don't know why such a trifle should come before the Egwugwu,' said one elder to the other.' Don't you know what kind of man Uzowulu is? He will not listen to any other decision,' replied the other." (Achebe 94) The elders knew that Uzowulu would still beat his wife after but it was a ritual of the Ibo, to bring serious cases of wife beating before the Egwugwu.

The Ibo also assigned other important roles to women as well as housewife. They painted the houses of the Egwugwu, and every Ibo man's first wife was paid more respect than his later wives were. During the palm wine ceremony at Nwakibie's Obi, none of the other wives were allowed to sit or begin to drink until Nwakibie's first wife arrived.

When Okonkwo was exiled from his village of Umuofia, and forced to return to his motherland, his mother's family accepted him, and helped him to adapt to his new village, despite his nasty attitude. A speech was given by Okonkwo's uncle, directed at him, shortly after he arrived. He asked Okonkwo if he knew why they often name their children Nneka, meaning, "Mother is supreme." Okonkwo did not know and shook his head. After laughing at his ignorance, Okonkwo's uncle Uchendu explained to him why they did this. He explained to Okonkwo that one's mother is always there for her children. He said, "A man belongs to his fatherland when things are good and life is sweet. But when there is sorrow and bitterness he finds refuge in his motherland. Your mother is there to protect you" (Achebe 134) He was trying to tell Okonkwo that a man will be happy and sad throughout his life, but when things get really bad, one's mother is always there to take care and comfort him.

The women of the tribe are seen as soft and female, and it is not good for the men to exhibit these traits, it means they are weak; at least this is how Okonkwo sees the women in his life. He is so desperately afraid of appearing weak to those around him, that he will do anything; even kill those close to him, to appear manlier. This may not be the way much of the tribes see their women, but Okonkwo is different. He is so afraid he will end up a failure like his father that he cannot see beyond the outside of people. Women are weak to him, and so, to appear weak to others is to appear effeminate, and there is nothing worse to this man. Early in the novel, Okonkwo's son, desperate to please his harsh father, learns he can no longer listen to the women when he is considered to be almost a man.

Achebe writes, "But he now knew that they were for foolish women and children, and he knew that his father wanted him to be a man. And so he feigned that he no longer cared for women's stories" (Achebe 38). Nwoye wants to please his father, but his father continually berates him for his womanly traits, like kindness and gentleness. Okonkwo sees these traits as weak and dreadful, and because they were the traits of his father, he despises them in his son, whom he sees as effeminate and weak. It is sad, because he alienates his son and literally 
drives him to the white man's religion, he also cannot see the goodness and decency in his son, and so dismisses him, just as he dismisses the rest of the women in the novel.

Throughout the novel, the theme of weakness comes up often, and always in comparison to women. Okonkwo is afraid to ever appear weak, and that is his tragic flaw. He could not see the goodness in his father, and so, he has allowed no goodness in himself. He is harsh to his children and his wives, and he does not learn or grow from his mistakes. He is the tragic hero of the story, but the women are also tragic, because they are so ignored and unloved by this strong man who cannot give of himself at all. However, the women do not need to be validated by Okonkwo; they are secure in their own strength, and in the strengths of the goddesses who are an important part of the culture.

In fact, "The Ibo people believe that the mother plays a major role in society. The movements and confrontations in the Ibo society, described by Achebe, do not militate against the position of women in society" (Egar 36). Thus, Okonkwo's harsh treatment of his wives would not be popular in his village, and while the men may not have said anything, it did set their minds against him. Okonkwo could only see violence as the solution to any problem, and that was not the way many people of his tribe thought people should act. In fact, many of the other Ibo admire him but distrust him at the same time. Achebe writes, "Indeed he respected him for his industry and success. But he was struck, as most people were, by Okonkwo's brusqueness in dealing with less successful men" (Achebe 19).

It is interesting to note that all of the tribesmen did not feel as Okonkwo did, although many of them certainly agreed with his assessment of women as the weaker sex. During his exile, another Ibo, Uchendu, encourages Okonkwo to experience his feminine side, and allow himself to feel, or he will surely be doomed. However, Okonkwo is so fearful of appearing weak that he cannot listen to anyone. He cannot learn from his past, and grow to his future. Okonkwo is so set in his prejudices against femininity, that he cannot see how strong the women of his tribe really are, and how he could learn from them. In reality, the Ibo women rioted in the early $1900 \mathrm{~s}$, after the white men began their takeover of Nigeria. It was the women who stood up to the invaders, and so, Okonkwo misses an opportunity to learn much from the strong women around him. In fact, Okonkwo misses many opportunities throughout the novel, and that is why he is a tragic figure.

Okonkwo's treatment of his wives, from beating them to ignoring them, also represents the brutal way the white man colonized Africa. The British missionaries in Things Fall Apart seem harmless enough, but they are bringing a new way of life that will someday erase the way of life the Ibo people know during the novel. British imperialism in Africa was all about money and power, and millions of people were thrown off their lands and forced to give up their rural ways. Some of the Ibo see this coming, and are afraid of the white man's encroachment.

While the missionaries were only there to convert the heathens, the white man in Africa was generally cruel and unyielding. The District Commissioner represents this prejudicial look at the natives, and his treatment of them is not that different from the treatment Okonkwo gives his family. It is diffident, violent, and disinterested, and that is the same way the District Commissioner handles the natives he hopes to dominate. Thus, the women in the novel are a symbol. They are a symbol of outdated beliefs, such as women are subservient to men, but they are also a symbol of the white man, and his indifference to the suffering created by his encroachment on the natives' land, and way of life.

The novel, especially the beginning, spells out in great detail many of the intricate customs and celebrations of the Ibo, and reading the novel illustrates just what these people lost when the white man came to Africa and forced them to adapt or die. One character warns Okonkwo about the whites, "We have heard stories about white men who made the powerful guns and the strong drinks and took slaves away across the seas, but no one thought the stories were true" (Achebe 99). Okonkwo could not adapt, and so he left his family to fend for themselves when they needed him most.

In the end, Okonkwo mourns "for the clan, which he saw breaking up and falling apart and he mourned for the warlike men of Umuofia, who had so unaccountably become soft like women" (Achebe 129). Even at the end of his life, Okonkwo cannot take responsibility for his own actions. He has driven away and disowned his son, he has alienated his wives and children by beating and berating them, and he has even gone into exile. Yet, he is still desperately afraid of appearing weak like a woman. He does not learn from his experiences, and he does not learn that there are far worse things than appearing womanly.

His son, Nwoye, is happy in his life with the whites, but Okonkwo cannot even accept that happiness. He is a sad figure, and it seems right somehow that he commits the ultimate act of weakness, suicide, because it is clear from the beginning of the story that Okonkwo cannot learn and grow. He cannot adapt to change, even when the old ways no longer work. The only thing that he can understand is violence, and it is the only thing that he thinks solves problems and makes a man a man. Achebe puts it this way, "Okonkwo encouraged the boys to sit with him in his $o b i$, and he told them stories of the land, masculine stories of violence and bloodshed" (Achebe 52). Okonkwo 
represents all men in society who are so obsessed with their own manliness that they can never allow themselves any emotion, caring, or concern. Sadly, these archaic attitudes are still not uncommon in today's society, and Okonkwo illustrates just how outdated and ridiculous they really are.

The women of the tribe are often silent, and they play a very minor role in the novel. This is true of the society as well. Achebe did not even give some of the women names. Women were simply not as important in Ibo society as men, but they did have some vital roles, and some of the men knew they could learn from the women. Okonkwo did not, and so, he could not survive in a changing world, that included men and women gathered together to try to hold on to a way of life that was swiftly disappearing.

In conclusion, the women of the tribes in this novel show how women all over the world have been treated in the past. They are seen as less than men; soft, weak, and only good enough to work in the fields and take care of the house. Yet, women are the backbone of any society, because not only do they perform much of the work, they bear and raise the children, and keep the society viable and successful. Many of the men in this novel, like Okonkwo, are foolish, and in the end, not strong enough to bear up to their new lives. The women of the novel are strong, and it is clear they will survive, no matter what.

\section{Things Fall Apart and Symbolic notions.}

The woman's treatment by the Ibo men is similar to the Ibo treatment by the whites, and so, they serve as a reminder by the author that there are always weak and strong in a society, and the weakest members may not be the most obvious, or the most vocal.

In the novel the religion is very important to the survival of the tribe and the people often work together for the betterment of the tribe. There are also individual aspects in the Ibo society. Each person has his own chi, or personal god. This personal god is to watch over a person and protect them. Some people have a stronger chi than others do, and they will achieve a higher standing in the society. This is very important to some of the people in the tribe, and Okonkwo is one of those people. He does a lot to help better the Ibo society, but he also wants to have a high standing in the Ibo society for himself.

Things Fall Apart, written by Chinua Achebe in 1958 just before Nigerian independence, demonstrates the violent societal conflict that resulted from British colonialism and arrival of the missionaries at the end of the nineteenth century. The longstanding structure and tradition of the Ibo culture is ripped apart when confronted with the completely disparate followings of the Christian Church. Achebe demonstrates that even a society with as strong a foundation as the Ibo people in Umuofia can have a vulnerability for which it has not prepared. As the natives clearly stated in the novel about the Imperial colonist: "He has put a knife on the things that held us together and we have fallen apart" (Achebe 162).

Briefly, the novel Things Fall Apart takes place in a late-1800s Nigerian Ibo village of Umuofia, prior to the arrival of the first Christian missionaries and British officials. The main character, Okonkwo, represents the tragic hero who has status, prestige, bravery, wealth and a strong desire to succeed to make up for his father's failings. However, as a tragic figure, Okonkwo's human flaws contribute to his downfall. More broadly, however, Okonkwo represents every man who must have a strong enough self-image and personal integrity to battle new ways and customs from a competitive culture.

Religious beliefs were deeply engrained in the Ibo culture, including a supreme God, known by various names in Ibo land such as Chukwu (the great God). Because Chukwu was all powerful, prayer and sacrifice was usually made to the lesser and more accessible spirits who continually were part of human affairs. Other divinities came from various areas of the natural world included Amadioha (lightning), Igwe (the sky) and Anyanwu (the sun).

Before the influence of Europeans and Christian missions, most Ibo practiced some form of ancestor worship, which believed to gain success in the day-to-day world. This could be accomplished in a number of ways including participation in the secret men's society, Mmo. The second level of initiates was responsible for carrying out the funeral ceremonies for the deceased and inducting the departed spirits into the after-world, so that they would stop causing mischief in the village. "Now and again an ancestral spirit or egwugwu. Appeared from the underworld, speaking in a tremulous, unearthly voice and completely covered in raffia," Achebe (114) recalls about a funeral rite of the elderly Ezeudu.

The role of the dead was fundamental in the Ibo religion. The principle of living man, his soul is obi or Nkpulobi, the heart, or the kernel of the heart. The muo of a dead man was not only made up of this soul isolated from the body, as Christians tend to believe. Instead, the Ibo spirits had a Para-body. The world of the spirits was a shadowy mirror of the real world, although with continual gloom, where the social hierarchy of the Ibo clan continued to exist. 
The Ibo and Christian religions differed in a number of other ways. The differences in the Christian religion were not easy for the Ibo to incorporate into their traditional beliefs. The missionaries often wrote about the alternating waves of conversion and backsliding. To the individual who believed in many spirits, the conflicting creeds of Christianity were difficult to accept. The doctrines of the Incarnation, Atonement and Trinity were especially difficult to incorporate, especially the first two that appeared to contradict the spiritual nature of God, as noted by in Things Fall Apart (Achebe 137) as the "mad logic of the Trinity."

On the other hand, "The white man was also their brother, because they were all sons of God" (Achebe 134). The question thus arose, how could they be brothers yet have religions that were so disparate? This made them question what was actually true. Whose religion was right, who's wrong? The mixed feelings were exacerbated by the British who told the Ibo people that their customs were bad and their gods were not true gods at all.

This created the beginning of a lasting rift between fellow clansmen and relatives who now differed in their beliefs. Those who first converted to Christianity were members not fully a part of the clan life. For example, the first woman convert was Nneka, who had to discard four sets of twins. Her husband and his family were becoming critical of her, so she fled to join the Christians where they would accept her present pregnancy. Most of the clan considered this a "good riddance" (Achebe 141). There was also the gentle Nwoye, who had been shunned because of his "less manly" ways and finds answers in the poetry of Christianity (Achebe 137).

The missionaries also forced the Ibo to break with their strong past and not pass on their stories to the next generation. As Achebe writes, "Among the Ibo the art of conversation is regarded very highly and proverbs are the palm-oil with which words are eaten" (Achebe 10). This would be equivalent today of destroying all written and visual communication.

Ironically, one of the main differences between the two cultures was the degree of allowance to kill. In fact, the British almost kill off an entire village in vengeance of the murder of one white man (Achebe 129). The Western tradition condoned people to fight each other over religion, such as in the Crusades, but the Ibo tradition forbade them to kill any present clan member. This was an abomination. Wars against other clans only took place when truly justified.

In his novel, Achebe recognizes the art of writing by showing the range of human traits— good and bad. He does not portray the Ibo clan as perfect in terms of when violence was allowed:

This is where the writer's integrity comes in. Will he be strong enough to overcome the temptation to select only those facts which flatter him? If he succumbs he will have branded himself as an untrustworthy witness... We can pretend that our past was one long, Technicolor idyll. "We have to admit that like other people's past ours had its good as well as its bad sides" (Achebe 1978, 9).

Okonkwo's level of prestige is shown by bestowing on him the duty of looking after Ikemefuna, a young boy from a neighboring village, who was sacrificed to avoid warfare and bloodshed. Ikemefuna is murdered for the sins of the clan, similar to the crucifixion of Jesus or, depicting the Old Testament, God's request to kill Isaac. Similarly, newborn twins were killed as a dishonor to the culture.

The missionary enterprise often seemed like an attack on the very structure of Ibo society, a society that had withheld myriad of challenges over centuries of time. Before the European colonial powers entered Africa, the Ibos "had a philosophy of great depth and value and beauty, in that they had poetry and, above all, they had dignity" (Achebe, 1978, 8).

The political functioning of the tribe was alien to the British colonists, who believed that all civilizations progressed as theirs had from tribes through monarchy and finally to parliamentary government. When arriving in Mbanta, the missionaries expected to meet a ruling king (Achebe 138). When finding no power with whom to work, the British set up its own political system that delegated rules from the English throne through district commissioners to native court messengers who did not in any way belong to the village government. "These court messengers (nicknamed "Ashy-Buttocks") were greatly hated in Umuofia because they were foreigners and also arrogant and high-handed" (Achebe 160).

Okonkwo inflexible traditionalism pitted him against his gentle son Nwoye, who joined the Christian European missionaries. In the novel, Oknokwo had to participate in a ceremonial human sacrifice and endure a seven-year exile after his gun accidentally killed the son of the deceased warrior Ezeudu. He also lost part of himself when he lost Ikemefuna. Upon returning to the village, he found it torn apart by Western Imperialism. Finally, he commits suicide after decapitating a white messenger who violated his authority.

Okonokwo's demise was brought about by breaking the sacred laws of the clan as well as unsuccessfully fighting against the unjust system of the colonists. He stands as a representation of his entire clan and other similar cultures who, through the centuries, have lost their traditions through the assault of Imperialism. Achebe's novel 
demonstrates that humanity, in both its best and worst cases, is represented in all cultures. Thus, it is imperative for any society that wants to survive to be prepared with all types of cultural intrusions. Ibo is strong as a just and democratic society, a moral code, economic base and arts and music. The society's Achilles' heal is that it did not recognize it had to build in a fail-safe power to combat even stronger outside forces and the ability to meet and adapt to radical change.

\section{Achebe's stylistic merits.}

In his novel Things Fall Apart, Chinua Achebe draws a lively portrait of a Nigerian people, the Ibo, at the end of the nineteenth century, when the British colonization began in Africa. Chinua Achebe's main achievement in the novel is that of accurately rendering a complex picture of the African cultural tradition and identity from the inside the tradition itself, that is, by telling a story of the Ibo people which speaks for itself and which sees life from the perspective of the Nigerian people and not from the outside. The most important message of the novel is clearly the gradual demise of the Ibo culture, of its traditions, customs and religion under the powerful wave of white European civilization.

This message is already enclosed in the title of the novel: Achebe describes in his novel the falling apart of the African culture. The Christian white missionaries in the novel, Mr. Brown and Rev. Smith, are a major cause of the things falling apart. It is obvious that Achebe, without being critical of Christianity as a religion, criticizes the methods that were used by the white colonizers to undermine the African culture. While the conversion tactics used by the two missionaries are very different; Mr. Brown is moderate and tries to establish a relationship with the people while Rev. Smith is overzealous and intransigent and instigates major conflicts inside the Umuofia clanboth contribute to the same end: the falling apart of a culture.

Thus, Mr. Brown's moderation in his conversion tactics is obviously contrasted with Rev. Smith's zealousness. Mr. Brown, the first who comes as a missionary, tries to temper some of the intemperate converts, such as Enoch for example, and thus keeps some of the conflicts inside the clan at bay. Also, he builds a school and a hospital for the village and tries to maintain peaceful relationships with everyone. He can be said to be successful in his practices in as much as he gains the respect of most of the members of the clan: "Mr. Brown preached against such excesses of zeal, and so Mr. Brown came to be respected even by the clan, because he trod softly on its faith"(Achebe 163).

By contrast, Rev. Smith is portrayed as intransigent and limited in his views, seeing things as either black or white, that is completely banishing the inferior African culture and religion and trying to bring it out of darkness into the light: "[He] saw things as black and white. And black was evil. He saw the world as a battlefield in which the children of light were locked in mortal combat with the sons of darkness. He spoke in his sermons about sheep and goats and about wheat and tares. He believed in slaying the prophet of Baal" (Achebe, 130). Rev. Smith encourages all the overzealous practices of the converts and causes Enoch to eat a python that was considered sacred by the clan. All these conflicts inside the Ibo people are irremediable wrongs that obviously cause the eventual demise of the culture itself.

Thus, the tactics of conversion used by the two missionaries are indeed contrastive, since Mr. Brown has taken some understanding while Rev. Smith has none, but they are not entirely opposite. There are many instances of the author's sarcasm with respect to the good intentions of both of the missionaries. First of all, the names he gives them put them on an equal footing: Brown and Smith are both typical, nondescript British names. Also, they both have the same obvious end in their missions: to submerge the African culture under the superior white one.

Achebe uses ironical, indirect devices to portray both of the methods used: Mr. Smith is seemingly a superior character who is greatly distressed by the ignorance of the people that he is trying to convert to the new religion and who believes, in contrast with Mr. Brown, that only a few, superior and overzealous elect people can have access to real faith: "Mr. Smith was greatly distressed by the ignorance which many of his flock showed even in such things as the Trinity and the Sacraments. It only showed that they were seeds sown on a rocky soil. Mr. Brown had thought of nothing but numbers. He should have known that the kingdom of God did not depend on large crowds. Our Lord Himself stressed the importance of fewness... Our Lord used the whip only once in His life -- to drive the crowd away from the Church."(Achebe, 169)

On the other hand, Mr. Brown seems to have an overall positive contribution to the African community. Nevertheless, the author ironically implies that there is indeed only a difference in method between the two missionaries, and the decline of the Ibo culture already began under the more lenient government of Mr. Brown. For example, the school he builds can be seen as another way to indoctrinate the clan. This school is in fact the cause of other conflicts inside the Ibo community, since by attending this school an Ibo could become a court messenger that is someone that would report and give out information from inside the clan to the white governors: "Mr. Brown's school produced quick results. A few months in it were enough to make one a court messenger or even a court clerk. Those who stayed longer became teachers: and from Umuofia laborers went forth into the 
Lord's vineyard. New churches were established in the surrounding villages and a few schools with them. From the very beginning religion and education went hand in hand." (Achebe, 166)

Moreover, it is hard to speak of success with any of these missionaries, since the author shows that what is achieved through the conversions and the indoctrination is merely a deepening of the gap between the two cultures, the white and the African. The Ibo people do not understand the new religion, but merely associate it with their own views of the world, a fact that shows the complete inadequacy of preaching it in the first place: "It was not the mad logic of the Trinity that captivated him. He did not understand it. It was the poetry of the new religion, something felt in the marrow" (Achebe, 137).

The irony of Achebe is obvious: through various methods, exemplified by the two missionaries, the white man insinuated his own culture in the African culture. Mr. Brown's soft tactic and Mr. Smith's loud one, have essentially the same effect of creating confusion and conflict among the Ibo people and thus, by bringing them apart, undermining the African culture itself: "The white man is very clever. He came quietly and peaceably with his religion. We were amused at his foolishness and allowed him to stay. Now he has won our brothers, and our clan can no longer act like one. He has put a knife on the things that held us together and we have fallen apart." (Achebe, 152) The conclusion is thus: Mr. Brown uses soft methods to convert the Ibo people, while Mr. Smith is a true religious tyrant, but both of them serve the same end eventually and bring destruction on the Nigerian tribe. Neither of them succeeds in anything more than causing things to fall apart by trying to civilize the Africans.

To emphasize the importance of this impact on the Ibo by the European autocracy, at the end of Things Fall Apart the narrator reveals the sorriest irony of all: the District Commissioner's mental absorption with a book he is writing, which he hopes to title The Pacification of the Primitive Tribes of the Lower Niger. It was not that the British had pacified the violent primitives. Rather it was that they had been too pacified to cope with the less pacified Western cultures.

The ending of the novel is a culmination of the author's irony: the District Commissioner intends to write a novel on the events that had taken place in Achebe's own novel: "The story of this man who had killed the messenger and hanged himself would make interesting reading. One could almost write a whole chapter on him. There was so much else to include, and one must be firm in cutting out details. He had already chosen the title of the novel, after much thought: The Pacification of the Primitive Tribes of the Lower Niger (Achebe, 191).

The novel that the Commissioner intends to write about Africa includes a small paragraph about Okonkwo's life proving the misunderstanding of the white people of the complex African culture. Okonkwo's tragedy described in Achebe's novel is thus the tragedy of the Ibo culture itself that falls apart under the new dominating white wave. Mr. Brown and Mr. Smith are both instruments for this destruction. The pacification of the primitive tribes is a typical phrase for the colonialist who were convinced that the African were savage people who needed their salvation, while Achebe's novel proves exactly the opposite, through the insight into real African tradition.

\section{References}

Achebe, C. (1978). "The Role of the Writer in a New Nation.". African Writers on African Writing. Ed. G.D. Killam. Evanston: Northwestern University Press.

(1996). Morning Yet on Creation Day. Portsmouth, NH: Heinemann.

(1996).Things Fall Apart. Portsmouth, NH: Heinemann.

(2000). Home and Exile. New York: Oxford University Press.

Egar, E. E. (2000). "Rhetorical Implications of the Theme in Things Fall Apart." In the Rhetorical Implications of Chinua Achebe's "Things Fall Apart." New York: University Press of America.

(2000). "Rhetorical Implications of Women and Their Pain in Things Fall Apart." In the Rhetorical Implications of Chinua Achebe's "Things Fall Apart." New York: University Press of America.

Jude, A. and Oseghale, F. (2008). "Wonder Women: Towards a Feminization of Heroism in the African Fiction A Study of the Heroines in Second Class Citizen and God's Bits of Wood." Journal of Education. Vol. 128. No. 4, Gale, Cengage Learning.

Noveler, M. K. ed. (2000 ). The Chinua Achebe Encyclopedia. Westport, Conn.: Greenwood Press.

Oseghale, F. and Oriahi, C. I. (2006). "Perspectives on Women's Education in the 21st Century." Journal of Academics . Vol. No. 1.

The Columbia Encyclopedia, 6th Edition. (2007). Columbia University Press. New York. 